\title{
Celebrating the 80th anniversary of hormone ablation for prostate cancer
}

\author{
Amina Zoubeidi@1 and Paramita M Ghosh 2,3,4 \\ 1Department of Urologic Sciences, University of British Columbia, Vancouver, British Columbia, Canada \\ 2Department of Urologic Surgery, School of Medicine, University of California Davis, Sacramento, California, USA \\ ${ }^{3}$ Department of Biochemistry and Molecular Medicine, School of Medicine, University of California Davis, Sacramento, California, USA \\ ${ }^{4}$ Department of Veterans Affairs, Northern California Health Care System, Mather, California, USA
}

Correspondence should be addressed to A Zoubeidi: azoubeidi@prostatecentre.com

This paper is part of a thematic review section celebrating 80 Years of Androgen Deprivation as a Treatment for Prostate Cancer. The guest editors for this section were Amina Zoubeidi and Paramita Ghosh. They were not involved in the review or editorial process for this paper, on which they are listed as authors.

\begin{abstract}
In this issue of Endocrine-Related Cancer, we are celebrating the 80th anniversary of hormone ablation as treatment for metastatic prostate cancer. Our understanding has evolved from the observation that androgen withdrawal, either surgical or pharmacological, resulted in prostatic atrophy in animal models, to its application in patients, to investigation of the mysterious way in which prostate cancer escapes androgen dependence. We are now in an era of novel AR pathway inhibitors, the combination of androgen ablation with chemotherapy, PARP inhibitors, immunotherapies, guided radiotherapy, and novel drug application based upon genetic testing of individual tumors. In this special issue, we bring together a collection of eight reviews that cover not only the history of 80 years of progress after the initial identification of androgen ablation as an effective treatment of prostate cancer, but subsequent improvements in the understanding of the biology of the disease, development of novel treatment paradigms, resistance to those treatments and disease progression following that resistance.
\end{abstract}

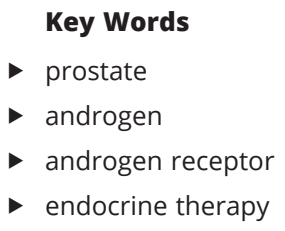

Endocrine-Related Cancer (2021) 28, T1-T10

\section{Introduction}

Localized prostate cancer can be treated with surgery; however, metastasized prostate cancer is usually treated with hormonal ablation. Improved diagnostic tools and earlier diagnosis has helped increase the 10-year survival of prostate cancer patients (Helgesen et al. 1996). By 1998, the 10-year relative survival for patients diagnosed with local and regional disease improved to 95\% (Brawley 2012), and is near 100\% today. Five-year survival for distant-stage prostate cancer improved to $32.3 \%$ by 2016 and remains at that level today (Siegel et al. 2020).
In this special issue of Endocrine-Related Cancer, we are celebrating the 80th anniversary of hormone ablation as a treatment for metastatic prostate cancer. Our understanding has evolved from the observation that androgen withdrawal, either surgical or pharmacological, resulted in prostatic atrophy in animal models, to its application in patients, to the investigation of the mysterious way in which prostate cancer escapes androgen dependence. We are now in an era of novel AR pathway inhibitors, the combination 
of androgen ablation with chemotherapy, PARP inhibitors, immunotherapies, guided radiotherapy, and novel drug application based upon genetic testing of individual tumors (Fig. 1). In this Anniversary Issue, we bring together a collection of eight reviews that cover not only the history of 80 years of progress after the initial identification of androgen ablation as an effective treatment of prostate cancer, but subsequent improvements in the understanding of the biology of the disease, development of novel treatment paradigms, resistance to those treatments and disease progression following that resistance.

\section{History}

In an article in this special issue, 'Targeting androgen receptor signaling: a historical perspective', Davies \& Zoubeidi (2021) outline the history of prostate cancer treatment using androgen ablation. An 18th century observation laid the foundation for the most important discovery of the 20th century in prostate cancer. The concept of androgen ablation was discussed as early as 1786 when John Hunter demonstrated that castration prevents prostate development in young bulls while inducing atrophy in adults (Hunter 1837). It was not until 1941 that Charles Huggins and Clarence Hodge performed the first castration surgically or by estrogen administration in eight patients with metastatic prostate cancer (Huggins et al. 1941). They observed that castration resulted in a decrease of serum acid-phosphatase and subsequently an increase in patient quality of life.

\section{Targeting adrenal androgen production}

In early 1960s, multiple clinical trials provided evidence that androgen ablation was merely palliative and not sufficient to cure prostate cancer, as Huggins noted that regression of the neoplasm is not complete (Huggins et al. 1941). Facing this challenge, new approaches of hormone manipulation were developed between 1960s and 1980s to block adrenal androgen production or androgen interaction to androgen receptor (Pavone-Macaluso et al. 1986, 1997, Trachtenberg et al. 2002). This was possible with the discovery of the structure of the hypothalamic hormone known as luteinizing hormone (LH)-releasing hormone (LHRH), which was shown to induce the pituitary to produce LH. LH binds to its receptor on the testes and activates testosterone production (outlined in Messner et al. 2020). Schally and Guillemin investigated ways to manipulate the hypothalamic-pituitary-gonadal axis and developed the first synthetic peptide agonists of LHRH (Tolis et al. 1982). Similarly, the antifungal ketoconazole (non-specific inhibitor of several cytochrome enzymes, involved in steroidogenesis including CYP17) accomplished PSA responses in some patients (Small et al. 1997, Kruit et al. 2004, Peer et al. 2014), but did not improve overall survival. This was traced to the fact that resistance to the treatment was observed in the majority of the patients.

\section{Targeting the androgen receptor}

The discovery of androgen receptor (AR) in late 1960s (Anderson \& Liao 1968, Bruchovsky \& Wilson 1968, Mainwaring 1969) revolutionized how we treat prostate

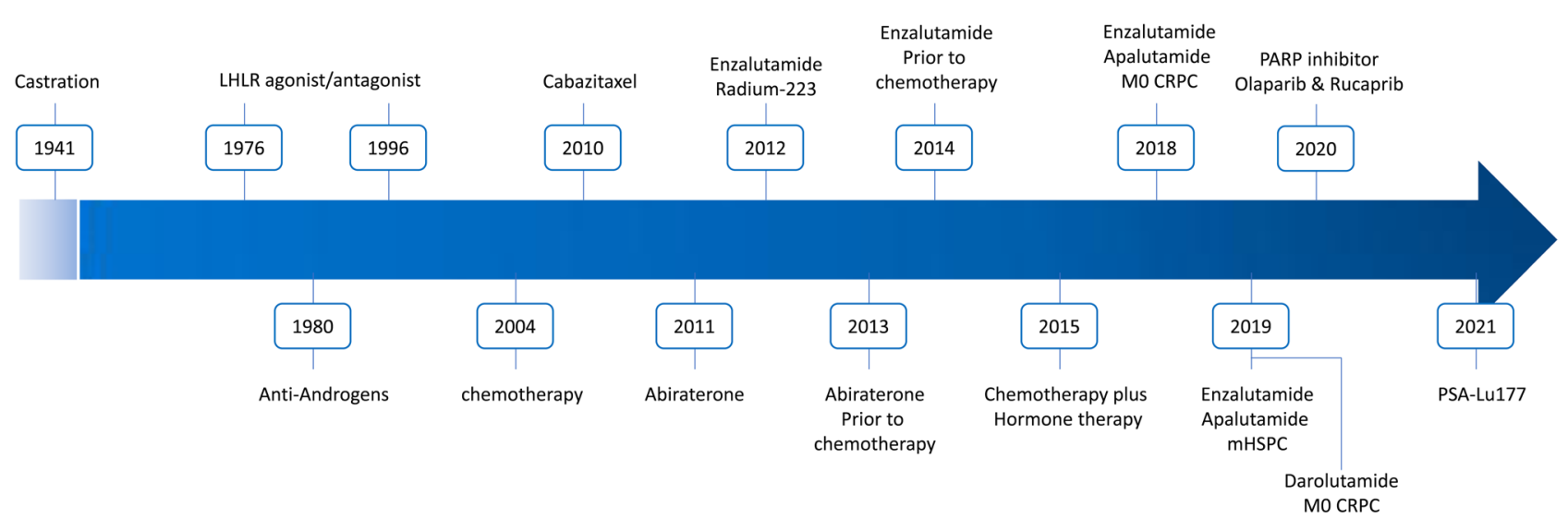

Figure 1

Treatment evolution of metastatic prostate cancer.

https://erc bioscientifica com https://doi.org/10.1530/ERC-21-0192 (c) 2021 Society for Endocrinology Published by Bioscientifica Ltd. Printed in Great Britain 
cancer today. The first AR antagonist targeting the AR ligand binding domain (LBD) proved to be as effective as castration (Pavone-Macaluso et al. 1986) and was approved by the US Federal Drug Administration (FDA) in late 1980s, which was followed by the development of non-steroidal anti-androgens, such as flutamide in 1989 and biclutamide in 1995, as treatment for prostate cancer (Wirth et al. 2007). Similar to castration, LHRH agonist/antagonist or AR inhibitors as monotherapy were shown to be ineffective, which shaped the path for combination therapy (Labrie et al. 1982, Lefebvre et al. 1982). Meta-analysis from 27 phase III clinical trials concluded that combined androgen blockade improved 5-year survival by about 5\% (Caubet et al. 1997, Bennett et al. 1999, Schmitt et al. 2001, Klotz 2008, Mitsiades et al. 2011); however, it invariably led to the development of castrate-resistant prostate cancer (CRPC) (Sayyid et al. 2017).

\section{Reviving old concepts with potent inhibitors}

In 'Androgen receptor signaling inhibitors: postchemotherapy, pre-chemotherapy and now in castrationsensitive prostate cancer', Mitsiades \& Kaochar (2021) ask 'Can a more comprehensive approach targeting all sources of androgenic stimulation delay emergence of resistance to ADT?' The development of CRPC was proposed to be caused by the low potency of AR antagonists and most likely prone to 'antagonist-to-agonist' conversion which was noticed in 15-30\% CRPC treated patients (Kelly \& Scher 1993, Leone et al. 2018). This phenomenon was also attributed to dysregulation of the AR complex via somaticacquired events, including $\mathrm{AR}$ LBD gain-of-function mutations, AR amplification, overexpression, altered recruitment of steroid receptor coactivators (Culig et al. 1999, Chen et al. 2004, 2009, Leone et al. 2018) as well as de novo synthesis of androgen via cholesterol metabolism (Locke et al. 2008, Cai et al. 2011). CYP17A1, a member of the cytochrome P450 enzyme family, promotes the synthesis of steroid hormones including testosterone and dehydroepiandrosterone (DHEA), both precursors of the strong AR ligand dihydrotestosterone (DHT) (outlined in Messner et al. 2020). These findings provided the rationale for drug discovery screens to identify novel anti-androgens and novel CYP17 inhibitors with better pharmacodynamics and more durable responses.

Despite the fact that ketoconazole itself did not show a survival benefit, it did serve as a forerunner of CYP17 inhibitors. Abiraterone acetate (Abi) was developed as a more effective inhibitor of CYP17 with significantly higher potency and selectivity than ketoconazole (Barrie et al. 1994, Potter et al. 1995, Rowlands et al. 1995, Haidar et al. 2003). The first phase I study for Abi enrolled 21 men with chemotherapy-naïve CRPC and found that Abi-treated patients experienced significant tumor shrinkage and dramatic falls in prostate-specific antigen (PSA) levels (Attard et al. 2008). In 2010, the pivotal phase III COU-AA-301 trial showed survival benefit and was approved in 2011 (de Bono et al. 2011).

Since CRPC was still driven by AR, second-generation ARLBD inhibitors were developed, including enzalutamide, apalutamide and darolutamide. Enzalutamide was initially tested in men with metastatic CRPC previously treated with docetaxel-based chemotherapy in the phase III AFFIRM trial, showed positive survival benefits (Scher et al. 2012) and was approved by the FDA in 2012 for latestage CRPC. Additional successful phase III clinical trials on enzalutamide were conducted including PREVAIL in men with asymptomatic metastatic CRPC without prior chemotherapy (Beer et al. 2014), and the ARCHES trial on men with high risk of metastatic progression or death in the castration-sensitive (CSPC) setting (Armstrong et al. 2019). It was later expanded to the setting of nonmetastatic CRPC (nmCRPC) in 2018 (Sternberg et al. 2020) and metastatic CSPC in 2019 (Davis et al. 2019). In addition, other AR inhibitors apalutamide and darolutamide which have improved safety profiles compared to enzalutamide, have also been approved for non-metastatic CRPC (Fizazi et al. 2019, 2020) or for metastatic CSPC (Chi et al. 2019).

Following clinical integration of second-line hormone therapy, growing evidence shows that CRPC patients are progressing on CYP17 and AR inhibitors even when they were administered sequentially (Loriot et al. 2013, Noonan et al. 2013, Bianchini et al. 2014, Azad et al. 2015, Attard et al. 2018, de Bono et al. 2018, Khalaf et al. 2019). Cross-resistance between these two classes of AR pathway inhibitors (ARPI) is not surprising, as several mechanisms can provide resistance to both CYP17 inhibitors and second generation anti-AR including constitutively active AR variants (including ARv7).

\section{Hormonotherapy and the bone microenvironment}

In 'Second-generation hormonotherapy in prostate cancer and bone microenvironment', Bouleftour et al. (2021) discuss the effect of androgen ablation and secondgeneration anti-androgens on the bone. Proper functioning of the AR is essential both for bone development and for 
bone mass maintenance (Bellido et al. 1995, Kawano et al. 2003, Chen et al. 2019). As a result, androgen ablation is significantly associated with bone loss and increased risk of bone fractures (Abu et al. 1997, Notelovitz 2002). In addition, most prostate cancer patients weare older, and naturally undergo age-related decline in hormonal levels and are highly prone to bone loss (Manolagas et al. 2013). The receptor activator of NF- $\kappa \mathrm{B}$ ligand (RANKL) gene, which encodes a major osteoclastogenesis inducer, was found to be a major regulator of bone density regulated by androgens (Kawano et al. 2003). Denosumab, a fully human MAB against RANKL, is used to improve bone mineral density and fractures in men receiving androgendeprivation therapy for non-metastatic prostate cancer (Smith et al. 2009). Despite this, prostate cancer patients, especially those who are older, suffer significantly from bone loss and related side effects. Bouleftour et al. (2021) argue that currently, specific recommendations for bone health management in prostate cancer patients are lacking, and prospective studies assessing bone mineral density in patients treated with second-generation hormone therapy has not been conducted. It may be hoped that the collection of information provided in this issue would pave the way for such a study.

\section{Emergence of aggressive variant prostate cancer}

Two articles in this special issue, 'The heterogeneity of prostate cancers lacking AR activity will require diverse treatment approaches' by Labrecque et al. (2021) and 'Therapy considerations in neuroendocrine prostate cancer: what next?' by Beltran \& Demichelis (2021) describe the advent of aggressive variant prostate cancers. Labrecque et al. describes $\mathrm{AR}$ indifferent and $\mathrm{AR}$ inactive prostate cancer and identify the role of SOX2, nBAF and LSD1 in the development of neuroendocrine prostate cancer. Beltran and Demichelis focus mainly on therapeutic aspects of neuroendocrine prostate cancer and identify numerous biomarkers that can predict its outcome.

With drugs targeting the AR pathway used in earlier disease settings, patients are living longer with longer exposure to systemic therapies. However, systemic therapies are not curative, and the treatment-resistant state remains a major medical problem. With the integration of potent ARPI, the archetypal course of prostate cancer was altered by the emergence of aggressive variants of prostate cancer with activated lineage programs. This includes amphicrine (expresses AR activity and neuroendocrine (NE) markers, retains luminal differentiation programs); AR-low (expresses low AR, high level of PSA and lacks NE markers); doublenegative prostate cancer (DNPC: lacks AR expression and activity and lacks NE markers) (Labrecque et al. 2019) and the treatment-induced neuroendocrine prostate cancer (NEPC: loss of AR signaling, expresses neuroendocrine markers) (Beltran et al. 2011, 2016). The complexity surrounding the transition from an AR-dependent to an AR-indifferent phenotype has made it difficult to define histological or molecular features that consistently associate with the emerging CRPC phenotypes. Currently, no morphological characteristics have been described in clinical specimens to delineate an AR-active from an AR-inactive phenotype in AR-expressing CRPC. Furthermore, it is not yet clear that morphological features associate with the full spectrum of molecular phenotypes of NEPC (Beltran et al. 2011, 2016, Aggarwal et al. 2018, Labrecque et al. 2019). With exception of loss of PTEN, RB1 and TP53, genomic analyses have not clarified genomic features that reliably distinguish these phenotypes or that can be used to predict risk of conversion to AR-null or NE-positive states. Epigenetic alterations, including changes in DNA methylation, chromatin accessibility, SWI/SNF, and histone markers are distinguishing features of NEPC, suggesting a key role of epigenetics in driving prostate cancer adenocarcinoma to NEPC (Dardenne et al. 2016, Cyrta et al. 2020, Baca et al. 2021). Activation and coordination of lineage determining transcription factors (e.g. ASCL1, BRN2, ONECUT2, MYCN, FOXA1) (Lee et al. 2016, Bishop et al. 2017, Guo et al. 2019, Baca et al. 2021) and pluripotency factors (e.g. SOX2) (Bishop et al. 2017) and downregulation of REST (Zhang et al. 2015) appear to drive lineage programming. This lineage reprogramming may be mediated by an intermediary, de-differentiated 'stem like' state before cells differentiate toward a NE-like phenotype with loss of AR dependence. Patient with aggressive variants of prostate cancer is treated with systemic therapy regimen. The combination of cabazitaxel and carboplatin is now supported by NCCN guidelines as an option for patients with aggressive variant clinical features or unfavorable genomics (loss of function alterations involving at least two of PTEN, TP53, and RB1) (Suzuki et al. 2020).

\section{Beyond hormone therapy DNA repair machinery targeting}

While AR-dependent transcriptional activity is the main driver of prostate cancer progression, genomic instability is a major feature of prostate cancer. This phenomenon is described by Díaz-Mejía et al. (2021) in this special issue
(C) 2021 Society for Endocrinology Published by Bioscientifica Ltd. Printed in Great Britain 
in the article entitled 'PARP inhibitors in prostate cancer: when to use them?'. This genomic instability is related to AR pathway and chronic inflammation leading to increased DNA damage (Godwin et al. 2013, Polkinghorn et al. 2013). These alterations in double-strand break repair genes will lead to impairment of error-free homologous recombination-mediated repair, favoring genomic instability and replicative stress. In prostate cancer, mutations of genes of the homologous recombination repair (HRR) and double strand break (DSB) pathways, mainly BRCA2, FANCA, RAD51 or PALB2; ATM, CHEK2 or CDK12, were observed 20-30\% of patients with advanced prostate cancer (Abida et al. 2017, Chung et al. 2019). Some of these mutations arise in the germline DNA and are hereditary and were found in other cancers, including pancreatic, ovarian and breast cancer (Sokolova et al. 2020), suggesting patients with prostate cancer can benefit from genetic testing and selected therapy beyond ARPI using PARP inhibitors. Hence PARP inhibitors were tested in multiple clinical trials, including the PROFOUND study (de Bono et al. 2020). This trial was structured around two cohorts: cohort A included 245 patients with mutations in BRCA1, BRCA2 or ATM; cohort B included 142 patients with alterations in any of the 12 other prespecified genes (BRIP1, BARD1, CDK12, 363 CHEK1, CHEK2, FANCL, PALB2, PPP2R2A, RAD51B, RAD51C, RAD51D, and RAD54L). The trial met the predefined threshold for overall survival and the PARP inhibitor olaparib was approved by FDA in 2020 for men with mCRPC and different DNA repair gene mutations offering a new treatment for these patients.

\section{Immunotherapy}

Although the effects of DNA repair defects and genetic/ epigenetic aberrations on the cell division machinery are increasingly well-defined, it has become evident that the tumor microenvironment (TME), including stroma, endothelial and immune cells, plays an important role in prostate cancer disease progression and survival (Hinshaw \& Shevde 2019). In this special issue, Kwon, Bryant and Parkes describe the role of immunotherapy in prostate cancer treatment in the article 'The tumor microenvironment and immune responses in prostate cancer' (Kwon et al. 2021). Large phase III clinical trials have failed to show improvement in overall survival with ipilimumab (a CTLA-4 inhibitor) (Kwon et al. 2014, Beer et al. 2017). However, these trials did demonstrate an acceptable toxicity profile, improved PFS with ipilimumab, and PSA response. Because of the limited benefit of monotherapy in the general setting, it was suggested that investigators select patients based on high genomic instability or mismatch repair efficiency that is known to increase neoantigen load with increased immune infiltration (Graham et al. 2020). Analysis of five clinical trials revealed that patients harboring genomic instability who received pembrolizumab reach objective response rate (Marcus et al. 2019). Because of the limited benefit of monotherapy, ongoing trials are investigating combination immunotherapy. For instance, the CheckMate trial evaluated ipilimumab and nivolumab for patients with mCRPC. Initial results have shown a response rate of $26 \%$ in the chemotherapy-naive cohort and $10 \%$ in the group who failed taxane-based therapy (Sharma et al. 2020).

\section{Radiation therapy}

Throughout the advances in the last several decades, radiotherapy (RT) has remained a pillar of treatment in localized advanced disease. Importantly, the addition of hormone therapy to adjuvant RT resulted in a significant improvement in progression-free survival (Pilepich et al. 2005). Sandoval, Dohm and Yamoah, in this special issue, describe the role of radiotherapy, with or without immunotherapy in 'Management of early-stage metastatic prostate cancer: appraisal of locoregional treatments and radiation therapy, with or without immunomodulation' (Sandoval et al. 2021). Analysis of the RTOG 9408 study showed that the benefit of hormone therapy was seen mostly in intermediate-risk disease and was likely insufficient for men with high-risk disease (Jones et al. 2011). In a large retrospective analysis of over 1300 post-prostatectomy patients who were either placed under observation or given hormone therapy \pm adjuvant $\mathrm{RT}$ showed significant increase in overall survival using androgen deprived therapy plus RT (Touijer et al. 2018). However, the HORRAD trial showed no difference in the overall survival in patient that received hormone therapy to those that received RT+hormone therapy (Boeve et al. 2019). Radium-223 is an alpha emitter that has been shown to target highly proliferative bone metastases (Bruland et al. 2006, Gomez-Veiga et al. 2018). Development of advanced assays and genomic risk stratification has increased the spectrum of using RT in prostate cancer. However, the use of RT in biochemicalrecurrent disease was challenging because of the lack of sensitive modalities to detect positive nodes. Recently a very sensitive approach was developed based on the prostate-specific membrane antigen (PSMA) PET/CT imaging and become the recommended imaging 
modality in the setting of rising PSA (Gillessen et al. 2020). Interestingly, PSMA can be used beyond imaging not only for PET imaging but in the linking to the beta emitter lutetium-177, which has provided a novel approach to treat prostate cancer patients showing an average PSA decline in $75 \%$ of patients, which was supported by radiographic evidence of objective responses and stable disease (Yadav et al. 2019).

\section{Current perspectives}

Over 80 years, tremendous advances were achieved leading to changes in clinical practice. We built on observations from 19th and 20th centuries and developed potent AR pathway inhibitors, discovered and validated novel markers, established novel modalities for imaging and treatment and innovated on how to run clinical trials. We accepted that prostate cancer is not one disease. Today, we stratify patients and employ genetic testing. Yet, metastatic prostate cancer patients still die with treatment-resistant aggressive disease. We are advancing our understanding of mechanisms of treatment resistance, identifying targets and novel drugs. However, the only way we can save lives is to conduct clinical studies, which will be challenging, especially for rare phenotypes. We recommend embracing the concept of the STAMPEDE trial to tackle this problem. Briefly, STAMPEDE was initiated in 2005, and it is an ongoing multi-arm, multistage randomized clinical trial conducted in the United Kingdom and Switzerland testing various treatment in newly diagnosed or relapsing high risk, node-positive, or metastatic prostate cancer patients initiating long term hormone therapy. The unique trial design permits for test arms to be added over time and compared with contemporary standard of care single ongoing control arm. Overall, STAMPEDE has established docetaxel, abiraterone, and radiotherapy as new first-line treatment options. 4000 patients have experienced a survival benefit on the completed arms in STAMPEDE (James et al. 2017, Parker et al. 2018, Clarke et al. 2019, 2020). We hope that with this series of reviews in this issue of Endocrine-Related Cancer, future investigators will better understand the scope of the work needed to make such a trial easier to implement.

\section{Declaration of interest}

The authors declare that there is no conflict of interest that could be perceived as prejudicing the impartiality of this review.

(c) 2021 Society for Endocrinology Published by Bioscientifica Ltd. Printed in Great Britain

\section{Funding}

The authors did not receive any specific grant from any funding agency in the public, commercial or not-for-profit sector for this work.

\section{References}

Abida W, Armenia J, Gopalan A, Brennan R, Walsh M, Barron D, Danila D, Rathkopf D, Morris M, Slovin S, et al. 2017 Prospective genomic profiling of prostate cancer across disease states reveals germline and somatic alterations that may affect clinical decision making. JCO Precision Oncology 1 PO.17.00029. (https://doi.org/10.1200/ po.17.00029)

Abu EO, Horner A, Kusec V, Triffitt JT \& Compston JE 1997 The localization of androgen receptors in human bone. Journal of Clinical Endocrinology and Metabolism 82 3493-3497. (https://doi.org/10.1210/jcem.82.10.4319)

Aggarwal R, Huang J, Alumkal JJ, Zhang L, Feng FY, Thomas GV, Weinstein AS, Friedl V, Zhang C, Witte ON., et al 2018 Clinical and genomic characterization of treatment-emergent small-cell neuroendocrine prostate cancer: a multi-institutional prospective study. Journal of Clinical Oncology 36 2492-2503. (https://doi. org/10.1200/JCO.2017.77.6880)

Anderson KM \& Liao S 1968 Selective retention of dihydrotestosterone by prostatic nuclei. Nature 219 277-279. (https://doi org/10.1038/219277a0)

Armstrong AJ, Szmulewitz RZ, Petrylak DP, Holzbeierlein J, Villers A, Azad A, Alcaraz A, Alekseev B, Iguchi T, Shore ND, et al. 2019 ARCHES: a randomized, phase III study of androgen deprivation therapy with enzalutamide or placebo in men with metastatic hormone-sensitive prostate cancer. Journal of Clinical Oncology 37 2974-2986. (https://doi. org/10.1200/JCO.19.00799)

Attard G, Reid AH, Yap TA, Raynaud F, Dowsett M, Settatree S, Barrett M, Parker C, Martins V, Folkerd E, et al. 2008 Phase I clinical trial of a selective inhibitor of CYP17, abiraterone acetate, confirms that castration-resistant prostate cancer commonly remains hormone driven. Journal of Clinical Oncology 26 4563-4571. (https://doi. org/10.1200/JCO.2007.15.9749)

Attard G, Borre M, Gurney H, Loriot Y, Andresen-Daniil C, Kalleda R, Pham T, Taplin ME \& PLATO Collaborators 2018 Abiraterone alone or in combination with enzalutamide in metastatic castration-resistant prostate cancer with rising prostate-specific antigen during enzalutamide treatment. Journal of Clinical Oncology 36 2639-2646. (https://doi.org/10.1200/JCO.2018.77.9827)

Azad AA, Eigl BJ, Murray RN, Kollmannsberger C \& Chi KN 2015 Efficacy of enzalutamide following abiraterone acetate in chemotherapy-naive metastatic castration-resistant prostate cancer patients. European Urology 67 23-29. (https://doi.org/10.1016/j.eururo.2014.06.045)

Baca SC, Takeda DY, Seo JH, Hwang J, Ku SY, Arafeh R, Arnoff T, Agarwal S, Bell C, O'Connor E, et al. 2021 Reprogramming of the FOXA1 cistrome in treatment-emergent neuroendocrine prostate cancer. Nature Communications 12 1979. (https://doi.org/10.1038/s41467-021-22139-7)

Barrie SE, Potter GA, Goddard PM, Haynes BP, Dowsett M \& Jarman M 1994 Pharmacology of novel steroidal inhibitors of cytochrome P450(17) alpha (17 alpha-hydroxylase/C17-20 lyase). Journal of Steroid Biochemistry and Molecular Biology 50 267-273. (https://doi. org/10.1016/0960-0760(94)90131-7)

Beer TM, Armstrong AJ, Rathkopf DE, Loriot Y, Sternberg CN, Higano CS, Iversen P, Bhattacharya S, Carles J, Chowdhury S, et al. 2014 Enzalutamide in metastatic prostate cancer before chemotherapy. New England Journal of Medicine 371 424-433. (https://doi.org/10.1056/ NEJMoa1405095)

Beer TM, Kwon ED, Drake CG, Fizazi K, Logothetis C, Gravis G, Ganju V, Polikoff J, Saad F, Humanski P, et al. 2017 Randomized, double-blind, phase III trial of ipilimumab versus placebo in asymptomatic or 
minimally symptomatic patients with metastatic chemotherapy-naive castration-resistant prostate cancer. Journal of Clinical Oncology 35 40-47. (https://doi.org/10.1200/JCO.2016.69.1584)

Bellido T, Jilka RL, Boyce BF, Girasole G, Broxmeyer H, Dalrymple SA, Murray R \& Manolagas SC 1995 Regulation of interleukin-6, osteoclastogenesis, and bone mass by androgens. The role of the androgen receptor. Journal of Clinical Investigation 95 2886-2895. (https://doi.org/10.1172/JCI117995)

Beltran H \& Demichelis F 2021 Therapy considerations in neuroendocrine prostate cancer: what next? Endocrine-Related Cancer 28 67-78. (https://doi.org/10.1530/ERC-21-0140)

Beltran H, Rickman DS, Park K, Chae SS, Sboner A, Macdonald TY, Wang Y, Sheikh KL, Terry S, Tagawa ST, et al. 2011 Molecular characterization of neuroendocrine prostate cancer and identification of new drug targets. Cancer Discovery 1 487-495. (https://doi. org/10.1158/2159-8290.CD-11-0130)

Beltran H, Prandi D, Mosquera JM, Benelli M, Puca L, Cyrta J, Marotz C, Giannopoulou E, Chakravarthi BV, Varambally S, et al. 2016 Divergent clonal evolution of castration-resistant neuroendocrine prostate cancer. Nature Medicine 22 298-305. (https://doi.org/10.1038/ nm.4045)

Bennett CL, Tosteson TD, Schmitt B, Weinberg PD, Ernstoff MS \& Ross SD 1999 Maximum androgen-blockade with medical or surgical castration in advanced prostate cancer: a meta-analysis of nine published randomized controlled trials and 4128 patients using flutamide. Prostate Cancer and Prostatic Diseases 2 4-8. (https://doi. org/10.1038/sj.pcan.4500265)

Bianchini D, Lorente D, Rodriguez-Vida A, Omlin A, Pezaro C, Ferraldeschi R, Zivi A, Attard G, Chowdhury S \& De Bono JS 2014 Antitumour activity of enzalutamide (MDV3100) in patients with metastatic castration-resistant prostate cancer (CRPC) pre-treated with docetaxel and abiraterone. European Journal of Cancer $\mathbf{5 0}$ 78-84. (https://doi.org/10.1016/j.ejca.2013.08.020)

Bishop JL, Thaper D, Vahid S, Davies A, Ketola K, Kuruma H, Jama R, Nip KM, Angeles A, Johnson F, et al. 2017 The master neural transcription factor BRN2 is an androgen receptor-suppressed driver of neuroendocrine differentiation in prostate cancer. Cancer Discovery 7 54-71. (https://doi.org/10.1158/2159-8290.CD-15-1263)

Boeve LMS, Hulshof MCCM, Vis AN, Zwinderman AH, Twisk JWR, Witjes WPJ, Delaere KPJ, Moorselaar RJAV, Verhagen PCMS \& Van Andel G 2019 Effect on survival of androgen deprivation therapy alone compared to androgen deprivation therapy combined with concurrent radiation therapy to the prostate in patients with primary bone metastatic prostate cancer in a prospective randomised clinical trial: data from the HORRAD trial. European Urology 75 410-418. (https://doi.org/10.1016/j.eururo.2018.09.008)

Bouleftour W, Boussoualim K, Sotton S, Vassal C, Thomas T, Magné N \& Guillot A 2021 Second-generation hormonotherapy in prostate cancer and bone microenvironment. Endocrine-Related Cancer 28 39-49. (https://doi.org/10.1530/ERC-21-0118)

Brawley OW 2012 Trends in prostate cancer in the United States. Journal of the National Cancer Institute: Monographs 2012 152-156. (https://doi. org/10.1093/jncimonographs/lgs035)

Bruchovsky N \& Wilson JD 1968 The intranuclear binding of testosterone and 5-alpha-androstan-17-beta-ol-3-one by rat prostate. Journal of Biological Chemistry 243 5953-5960. (https://doi.org/10.1016/S00219258(18)94513-8)

Bruland ØS, Nilsson S, Fisher DR \& Larsen RH 2006 High-linear energy transfer irradiation targeted to skeletal metastases by the alpha-emitter 223Ra: adjuvant or alternative to conventional modalities? Clinical Cancer Research 12 6250s-6257s. (https://doi.org/10.1158/1078-0432. CCR-06-0841)

Cai C, Chen S, Ng P, Bubley GJ, Nelson PS, Mostaghel EA, Marck B, Matsumoto AM, Simon NI, Wang H, et al. 2011 Intratumoral de novo steroid synthesis activates androgen receptor in castration-resistant prostate cancer and is upregulated by treatment with CYP17A1 inhibitors. Cancer Research 71 6503-6513. (https://doi. org/10.1158/0008-5472.CAN-11-0532)

Caubet JF, Tosteson TD, Dong EW, Naylon EM, Whiting GW, Ernstoff MS \& Ross SD 1997 Maximum androgen blockade in advanced prostate cancer: a meta-analysis of published randomized controlled trials using nonsteroidal antiandrogens. Urology 49 71-78. (https://doi. org/10.1016/S0090-4295(96)00325-1)

Chen CD, Welsbie DS, Tran C, Baek SH, Chen R, Vessella R, Rosenfeld MG \& Sawyers CL 2004 Molecular determinants of resistance to antiandrogen therapy. Nature Medicine 10 33-39. (https://doi.org/10.1038/nm972)

Chen Y, Clegg NJ \& Scher HI 2009 Anti-androgens and androgendepleting therapies in prostate cancer: new agents for an established target. Lancet: Oncology 10 981-991. (https://doi.org/10.1016/S14702045(09)70229-3)

Chen JF, Lin PW, Tsai YR, Yang YC \& Kang HY 2019 Androgens and androgen receptor actions on bone health and disease: from androgen deficiency to androgen therapy. Cells 8 1318. (https://doi.org/10.3390/ cells8111318)

Chi KN, Agarwal N, Bjartell A, Chung BH, Pereira De Santana Gomes AJ, Given R, Juárez Soto Á, Merseburger AS, Özgüroğlu M, Uemura H., et al 2019 Apalutamide for metastatic, castration-sensitive prostate cancer. New England Journal of Medicine 381 13-24. (https://doi.org/10.1056/ NEJMoa1903307)

Chung JH, Dewal N, Sokol E, Mathew P, Whitehead R, Millis SZ, Frampton GM, Bratslavsky G, Pal SK, Lee RJ, et al. 2019 Prospective comprehensive genomic profiling of primary and metastatic prostate tumors. JCO Precision Oncology 3 PO.18.00283. (https://doi. org/10.1200/PO.18.00283)

Clarke NW, Ali A, Ingleby FC, Hoyle A, Amos CL, Attard G, Brawley CD, Calvert J, Chowdhury S, Cook A, et al. 2019 Addition of docetaxel to hormonal therapy in low- and high-burden metastatic hormone sensitive prostate cancer: long-term survival results from the STAMPEDE trial. Annals of Oncology 30 1992-2003. (https://doi. org/10.1093/annonc/mdz396)

Clarke NW, Ali A, Ingleby FC, Hoyle A, Amos CL, Attard G, Brawley CD, Calvert J, Chowdhury S, Cook A, et al. 2020 Corrigendum to addition of docetaxel to hormonal therapy in low- and high-burden metastatic hormone sensitive prostate cancer: long-term survival results from the STAMPEDE trial. Annals of Oncology 31 1992-2003. (https://doi. org/10.1016/j.annonc.2020.01.002)

Culig Z, Hoffmann J, Erdel M, Eder IE, Hobisch A, Hittmair A, Bartsch G, Utermann G, Schneider MR, Parczyk K, et al. 1999 Switch from antagonist to agonist of the androgen receptor bicalutamide is associated with prostate tumour progression in a new model system. British Journal of Cancer 81 242-251. (https://doi.org/10.1038/sj. bjc.6690684)

Cyrta J, Augspach A, De Filippo MR, Prandi D, Thienger P, Benelli M, Cooley V, Bareja R, Wilkes D, Chae SS, et al. 2020 Role of specialized composition of SWI/SNF complexes in prostate cancer lineage plasticity. Nature Communications 11 5549. (https://doi.org/10.1038/ s41467-020-19328-1)

Dardenne E, Beltran H, Benelli M, Gayvert K, Berger A, Puca L, Cyrta J, Sboner A, Noorzad Z, Macdonald T, et al. 2016 N-Myc induces an EZH2-mediated transcriptional program driving neuroendocrine prostate cancer. Cancer Cell 30 563-577. (https://doi.org/10.1016/j. ccell.2016.09.005)

Davies AH \& Zoubeidi A 2021 Targeting androgen receptor signaling: a historical perspective. Endocrine-Related Cancer 28 11-18. (https://doi. org/10.1530/ERC-21-0116)

Davis ID, Martin AJ, Stockler MR, Begbie S, Chi KN, Chowdhury S, Coskinas X, Frydenberg M, Hague WE, Horvath LG, et al. 2019 Enzalutamide with standard first-line therapy in metastatic prostate cancer. New England Journal of Medicine 381 121-131. (https://doi. org/10.1056/NEJMoa1903835)

de Bono JS, Logothetis CJ, Molina A, Fizazi K, North S, Chu L, Chi KN, Jones RJ, Goodman Jr OB, Saad F, et al. 2011 Abiraterone and increased https://erc.bioscientifica.com

https://doi.org/10.1530/ERC-21-0192 (c) 2021 Society for Endocrinology Published by Bioscientifica Ltd. Printed in Great Britain 
survival in metastatic prostate cancer. New England Journal of Medicine 364 1995-2005. (https://doi.org/10.1056/NEJMoa1014618)

de Bono JS, Chowdhury S, Feyerabend S, Elliott T, Grande E, MelhemBertrandt A, Baron B, Hirmand M, Werbrouck P \& Fizazi K 2018 Antitumour activity and safety of enzalutamide in patients with metastatic castration-resistant prostate cancer previously treated with abiraterone acetate plus prednisone for $\geq 24$ weeks in Europe. European Urology 74 37-45. (https://doi.org/10.1016/j.eururo.2017.07.035)

de Bono J, Mateo J, Fizazi K, Saad F, Shore N, Sandhu S, Chi KN, Sartor O, Agarwal N, Olmos D, et al. 2020 Olaparib for metastatic castrationresistant prostate cancer. New England Journal of Medicine 382 2091-2102. (https://doi.org/10.1056/NEJMoa1911440)

Díaz-Mejía N, García-Illescas D, Morales-Barrera R, Suarez C, Planas J, Maldonado X, Carles J \& Mateo J 2021 PARP inhibitors in prostate cancer: when to use them? Endocrine-Related Cancer 28 79-93. (https:// doi.org/10.1530/ERC-21-0133)

Fizazi K, Shore N, Tammela TL, Ulys A, Vjaters E, Polyakov S, Jievaltas M, Luz M, Alekseev B, Kuss I, et al. 2019 Darolutamide in nonmetastatic, castration-resistant prostate cancer. New England Journal of Medicine 380 1235-1246. (https://doi.org/10.1056/NEJMoa1815671)

Fizazi K, Shore N, Tammela TL, Ulys A, Vjaters E, Polyakov S, Jievaltas M, Luz M, Alekseev B, Kuss I, et al. 2020 Nonmetastatic, castrationresistant prostate cancer and survival with darolutamide. New England Journal of Medicine 383 1040-1049. (https://doi.org/10.1056/ NEJMoa2001342)

Gillessen S, Attard G, Beer TM, Beltran H, Bjartell A, Bossi A, Briganti A, Bristow RG, Chi KN, Clarke N, et al. 2020 Management of patients with advanced prostate cancer: report of the advanced prostate cancer consensus conference 2019. European Urology 77 508-547. (https://doi. org/10.1016/j.eururo.2020.01.012)

Godwin P, Baird AM, Heavey S, Barr MP, O'Byrne KJ \& Gately K 2013 Targeting nuclear factor-kappa $\mathrm{B}$ to overcome resistance to chemotherapy. Frontiers in Oncology 3 120. (https://doi.org/10.3389/ fonc.2013.00120)

Gomez-Veiga F, Alvarez-Ossorio JL, Carballido-Rodriguez J, Juarez-Soto A, Rodriguez-Antolin A \& Cozar-Olmo JM 2018 Radium-223 for the treatment of metastatic castration-resistant prostate cancer: a window of opportunity. Actas Urologicas Espanolas 42 616-624. (https://doi. org/10.1016/j.acuro.2018.05.004)

Graham LS, Montgomery B, Cheng HH, Yu EY, Nelson PS, Pritchard C, Erickson S, Alva A \& Schweizer MT 2020 Mismatch repair deficiency in metastatic prostate cancer: response to PD-1 blockade and standard therapies. PLoS ONE 15 e0233260. (https://doi.org/10.1371/journal. pone.0233260)

Guo H, CI, X, Ahmed M, Hua JT, Soares F, Lin D, Puca L, Vosoughi A, Xue H, et al. 2019 ONECUT2 is a driver of neuroendocrine prostate cancer. Nature Communications 10278.

Haidar S, Ehmer PB, Barassin S, Batzl-Hartmann C \& Hartmann RW 2003 Effects of novel 17alpha-hydroxylase/C17, 20-lyase (P450 17, CYP 17) inhibitors on androgen biosynthesis in vitro and in vivo. Journal of Steroid Biochemistry and Molecular Biology 84 555-562. (https://doi. org/10.1016/s0960-0760(03)00070-0)

Helgesen F, Holmberg L, Johansson JE, Bergström R \& Adami HO 1996 Trends in prostate cancer survival in Sweden, 1960 through 1988: evidence of increasing diagnosis of nonlethal tumors. Journal of the National Cancer Institute 88 1216-1221. (https://doi.org/10.1093/ jnci/88.17.1216)

Hinshaw DC \& Shevde LA 2019 The tumor microenvironment innately modulates cancer progression. Cancer Research 79 4557-4566. (https:// doi.org/10.1158/0008-5472.CAN-18-3962)

Huggins C, Stephens RC \& Hodges CV 1941 Studies on prostatic cancer: 2. The effects of castration on advanced carcinoma of the prostate gland. Archives of Surgery 43 209-233. (https://doi.org/10.1001/ archsurg.1941.01210140043004)

Hunter J 1837 The Works of John Hunter F. R. S. with Notes. London: Longman.
James ND, De Bono JS, Spears MR, Clarke NW, Mason MD, Dearnaley DP, Ritchie AWS, Amos CL, Gilson C, Jones RJ, et al. 2017 Abiraterone for prostate cancer not previously treated with hormone therapy. New England Journal of Medicine 377 338-351. (https://doi.org/10.1056/ NEJMoa1702900)

Jones CU, Hunt D, Mcgowan DG, Amin MB, Chetner MP, Bruner DW, Leibenhaut MH, Husain SM, Rotman M, Souhami L, et al. 2011 Radiotherapy and short-term androgen deprivation for localized prostate cancer. New England Journal of Medicine 365 107-118. (https:// doi.org/10.1056/NEJMoa1012348)

Kawano H, Sato T, Yamada T, Matsumoto T, Sekine K, Watanabe T, Nakamura T, Fukuda T, Yoshimura K, Yoshizawa T, et al. 2003 Suppressive function of androgen receptor in bone resorption. PNAS 100 9416-9421. (https://doi.org/10.1073/pnas.1533500100)

Kelly WK \& Scher HI 1993 Prostate specific antigen decline after antiandrogen withdrawal: the flutamide withdrawal syndrome. Journal of Urology 149 607-609. (https://doi.org/10.1016/s0022-5347(17)36163-3)

Khalaf DJ, Annala M, Taavitsainen S, Finch DL, Oja C, Vergidis J, Zulfiqar M, Sunderland K, Azad AA, Kollmannsberger CK, et al. 2019 Optimal sequencing of enzalutamide and abiraterone acetate plus prednisone in metastatic castration-resistant prostate cancer: a multicentre, randomised, open-label, phase 2, crossover trial. Lancet: Oncology 20 1730-1739. (https://doi.org/10.1016/S1470-2045(19)30688-6)

Klotz L 2008 Maximal androgen blockade for advanced prostate cancer. Best Practice and Research: Clinical Endocrinology and Metabolism 22 331-340. (https://doi.org/10.1016/j.beem.2008.01.004)

Kruit WH, Stoter G \& Klijn JG 2004 Effect of combination therapy with aminoglutethimide and hydrocortisone on prostate-specific antigen response in metastatic prostate cancer refractory to standard endocrine therapy. Anti-Cancer Drugs 15 843-847. (https://doi. org/10.1097/00001813-200410000-00004)

Kwon ED, Drake CG, Scher HI, Fizazi K, Bossi A, Van Den Eertwegh AJ, Krainer M, Houede N, Santos R, Mahammedi H, et al. 2014 Ipilimumab versus placebo after radiotherapy in patients with metastatic castration-resistant prostate cancer that had progressed after docetaxel chemotherapy (CA184-043): a multicentre, randomised, double-blind, phase 3 trial. Lancet: Oncology 15 700-712. (https://doi.org/10.1016/ S1470-2045(14)70189-5)

Kwon JTW, Bryant RJ \& Parkes EE 2021 The tumor microenvironment and immune responses in prostate cancer. Endocrine-Related Cancer $\mathbf{2 8}$ 95-107. (https://doi.org/10.1530/ERC-21-0149)

Labrecque MP, Coleman IM, Brown LG, True LD, Kollath L, Lakely B, Nguyen HM, Yang YC, Da Costa RMG, Kaipainen A, et al. 2019 Molecular profiling stratifies diverse phenotypes of treatmentrefractory metastatic castration-resistant prostate cancer. Journal of Clinical Investigation 129 4492-4505. (https://doi.org/10.1172/ JCI128212)

Labrecque MP, Alumkal JJ, Coleman IM, Nelson PS \& Morrissey C 2021 The heterogeneity of prostate cancers lacking AR activity will require diverse treatment approaches. Endocrine-Related Cancer 28 51-66. (https://doi.org/10.1530/ERC-21-0002)

Labrie F, Dupont A, Belanger A, Cusan L, Lacourciere Y, Monfette G, Laberge JG, Emond JP, Fazekas AT, Raynaud JP, et al. 1982 New hormonal therapy in prostatic carcinoma: combined treatment with an LHRH agonist and an antiandrogen. Clinical and Investigative Medicine 5 267-275.

Lee JK, Phillips JW, Smith BA, Park JW, Stoyanova T, Mccaffrey EF, Baertsch R, Sokolov A, Meyerowitz JG, Mathis C, et al. 2016 N-Myc drives neuroendocrine prostate cancer initiated from human prostate epithelial cells. Cancer Cell 29 536-547. (https://doi.org/10.1016/j. ccell.2016.03.001)

Lefebvre FA, Seguin C, Belanger A, Caron S, Sairam MR, Raynaud JP \& Labrie F 1982 Combined long-term treatment with an LHRH agonist and a pure antiandrogen blocks androgenic influence in the rat. Prostate 3 569-578. (https://doi.org/10.1002/pros.2990030606) (c) 2021 Society for Endocrinology Published by Bioscientifica Ltd. Printed in Great Britain 
Leone G, Tucci M, Buttigliero C, Zichi C, Pignataro D, Bironzo P, Vignani F, Scagliotti GV \& Di Maio M 2018 Antiandrogen withdrawal syndrome (AAWS) in the treatment of patients with prostate cancer. EndocrineRelated Cancer 25 R1-R9. (https://doi.org/10.1530/ERC-17-0355)

Locke JA, Guns ES, Lubik AA, Adomat HH, Hendy SC, Wood CA, Ettinger SL, Gleave ME \& Nelson CC 2008 Androgen levels increase by intratumoral de novo steroidogenesis during progression of castrationresistant prostate cancer. Cancer Research 68 6407-6415. (https://doi. org/10.1158/0008-5472.CAN-07-5997)

Loriot Y, Bianchini D, Ileana E, Sandhu S, Patrikidou A, Pezaro C, Albiges L, Attard G, Fizazi K, De Bono JS, et al. 2013 Antitumour activity of abiraterone acetate against metastatic castration-resistant prostate cancer progressing after docetaxel and enzalutamide (MDV3100). Annals of Oncology 24 1807-1812. (https://doi. org/10.1093/annonc/mdt136)

Mainwaring WI 1969 A soluble androgen receptor in the cytoplasm of rat prostate. Journal of Endocrinology 45 531-541. (https://doi.org/10.1677/ joe.0.0450531)

Manolagas SC, O'BRIEN CA \& Almeida M 2013 The role of estrogen and androgen receptors in bone health and disease. Nature Reviews: Endocrinology 9 699-712. (https://doi.org/10.1038/nrendo.2013.179)

Marcus L, Lemery SJ, Keegan P \& Pazdur R 2019 FDA approval summary: pembrolizumab for the treatment of microsatellite instability-high solid tumors. Clinical Cancer Research 25 3753-3758. (https://doi. org/10.1158/1078-0432.CCR-18-4070)

Messner EA, Steele TM, Tsamouri MM, Hejazi N, Gao AC, Mudryj M \& Ghosh PM 2020 The androgen receptor in prostate cancer: effect of structure, ligands and spliced variants on therapy. Biomedicines $\mathbf{8} 422$. (https://doi.org/10.3390/biomedicines8100422)

Mitsiades N, Chen Y \& Scher HI 2011 The AR axis as a pathogenetic mechanism and therapeutic target throughout the clinical states of prostate cancer: opportunities for second-line hormonal manipulations in castration-resistant prostate cancer. In Comprehensive Textbook of Genitourinary Oncology, 4th ed. Eds PT Scardino, WM Linehan, MJ Zelefsky, et al. Alphen aan den Rijn, Netherlands: Wolters Kluwer.

Mitsiades N \& Kaochar S 2021 Androgen receptor signaling inhibitors: post-chemotherapy, pre-chemotherapy and now in castrationsensitive prostate cancer. Endocrine-Related Cancer 28 19-38. (https:// doi.org/10.1530/ERC-21-0098)

Noonan KL, North S, Bitting RL, Armstrong AJ, Ellard SL \& Chi KN 2013 Clinical activity of abiraterone acetate in patients with metastatic castration-resistant prostate cancer progressing after enzalutamide. Annals of Oncology 24 1802-1807. (https://doi.org/10.1093/annonc/ mdt138)

Notelovitz M 2002 Androgen effects on bone and muscle. Fertility and Sterility 77 (Supplement 4) S34-S41. (https://doi.org/10.1016/s00150282(02)02968-0)

Parker CC, James ND, Brawley CD, Clarke NW, Hoyle AP, Ali A, Ritchie AWS, Attard G, Chowdhury S, Cross W, et al. 2018 Radiotherapy to the primary tumour for newly diagnosed, metastatic prostate cancer (STAMPEDE): a randomised controlled phase 3 trial. Lancet 392 2353-2366. (https://doi.org/10.1016/S01406736(18)32486-3)

Pavone-Macaluso M, De Voogt HJ, Viggiano G, Barasolo E, Lardennois B, De Pauw M \& Sylvester R 1986 Comparison of diethylstilbestrol, cyproterone acetate and medroxyprogesterone acetate in the treatment of advanced prostatic cancer: final analysis of a randomized phase III trial of the European Organization for Research on Treatment of Cancer Urological Group. Journal of Urology 136 624-631. (https:// doi.org/10.1016/s0022-5347(17)44996-2)

Pavone-Macaluso M, Corselli G, Ingargiola GB \& Serretta V 1997 The Urologic Cooperative Group of the EORTC. Structure, scope, research, results. Archivio Italiano di Urologia, Andrologia 69 209-215.

Peer A, Gottfried M, Sinibaldi V, Carducci MA, Eisenberger MA, Sella A, Leibowitz-Amit R, Berger R \& Keizman D 2014 Comparison of abiraterone acetate versus ketoconazole in patients with metastatic castration resistant prostate cancer refractory to docetaxel. Prostate $\mathbf{7 4}$ 433-440. (https://doi.org/10.1002/pros.22765)

Pilepich MV, Winter K, Lawton CA, Krisch RE, Wolkov HB, Movsas B, Hug EB, Asbell SO \& Grignon D 2005 Androgen suppression adjuvant to definitive radiotherapy in prostate carcinoma - long-term results of phase III RTOG 85-31. International Journal of Radiation Oncology, Biology, Physics 61 1285-1290. (https://doi.org/10.1016/j.ijrobp.2004.08.047)

Polkinghorn WR, Parker JS, Lee MX, Kass EM, Spratt DE, Iaquinta PJ, Arora VK, Yen WF, Cai L, Zheng D, et al. 2013 Androgen receptor signaling regulates DNA repair in prostate cancers. Cancer Discovery 3 1245-1253. (https://doi.org/10.1158/2159-8290.CD-13-0172)

Potter GA, Barrie SE, Jarman M \& Rowlands MG 1995 Novel steroidal inhibitors of human cytochrome P45017 alpha (17 alpha-hydroxylaseC17,20-lyase): potential agents for the treatment of prostatic cancer. Journal of Medicinal Chemistry 38 2463-2471. (https://doi.org/10.1021/ jm00013a022)

Rowlands MG, Barrie SE, Chan F, Houghton J, Jarman M, Mccague R \& Potter GA 1995 Esters of 3-pyridylacetic acid that combine potent inhibition of 17 alpha-hydroxylase/C17,20-lyase (cytochrome P45017 alpha) with resistance to esterase hydrolysis. Journal of Medicinal Chemistry 38 4191-4197. (https://doi.org/10.1021/jm00021a008)

Sandoval ML, Dohm A \& Yamoah K 2021 Management of early-stage metastatic prostate cancer: appraisal of locoregional treatments and radiation therapy, with or without immunomodulation. EndocrineRelated Cancer 28 109-120. (https://doi.org/10.1530/ERC-21-0073)

Sayyid RK, Evans A, Hersey K, Maloni R, Hurtado-Coll A, Kulkarni G, Finelli A, Zlotta AR, Hamilton R, Gleave M, et al. 2017 A phase II, randomized, open-label study of neoadjuvant degarelix versus LHRH agonist in prostate cancer patients prior to radical prostatectomy. Clinical Cancer Research 23 1974-1980. (https://doi.org/10.1158/10780432.CCR-16-1790)

Scher HI, Fizazi K, Saad F, Taplin ME, Sternberg CN, Miller K, De Wit R, Mulders P, Chi KN, Shore ND, et al. 2012 Increased survival with enzalutamide in prostate cancer after chemotherapy. New England Journal of Medicine 367 1187-1197. (https://doi.org/10.1056/ NEJMoa1207506)

Schmitt B, Wilt TJ, Schellhammer PF, Demasi V, Sartor O, Crawford ED \& Bennett CL 2001 Combined androgen blockade with nonsteroidal antiandrogens for advanced prostate cancer: a systematic review. Urology 57 727-732. (https://doi.org/10.1016/s0090-4295(00)01086-4)

Sharma P, Pachynski RK, Narayan V, Flechon A, Gravis G, Galsky MD, Mahammedi H, Patnaik A, Subudhi SK, Ciprotti M, et al. 2020 Nivolumab plus ipilimumab for metastatic castration-resistant prostate cancer: preliminary analysis of patients in the CheckMate 650 trial. Cancer Cell 38 489.e3-499.e3. (https://doi.org/10.1016/j. ccell.2020.08.007)

Siegel DA, O'Neil ME, Richards TB, Dowling NF \& Weir HK 2020 Prostate cancer incidence and survival, by stage and race/ethnicity - United States, 2001-2017. Morbidity and Mortality Weekly Report 69 1473-1480. (https://doi.org/10.15585/mmwr.mm6941a1)

Small EJ, Baron AD, Fippin L \& Apodaca D 1997 Ketoconazole retains activity in advanced prostate cancer patients with progression despite flutamide withdrawal. Journal of Urology 157 1204-1207. (https://doi. org/10.1016/S0022-5347(01)64924-3)

Smith MR, Egerdie B, Hernández Toriz N, Feldman R, Tammela TL, Saad F, Heracek J, Szwedowski M, Ke C, Kupic A, et al. 2009 Denosumab in men receiving androgen-deprivation therapy for prostate cancer. New England Journal of Medicine 361 745-755. (https://doi.org/10.1056/ NEJMoa0809003)

Sokolova AO, Yu EY \& Cheng HH 2020 Honing in on PARPi response in prostate cancer: from HR pathway to gene-by-gene granularity. Clinical Cancer Research 26 2439-2440. (https://doi.org/10.1158/1078-0432. CCR-20-0707)

Sternberg CN, Fizazi K, Saad F, Shore ND, De Giorgi U, Penson DF, Ferreira U, Efstathiou E, Madziarska K, Kolinsky MP, et al. 2020 
Enzalutamide and survival in nonmetastatic, castration-resistant prostate cancer. New England Journal of Medicine 382 2197-2206. (https://doi.org/10.1056/NEJMoa2003892)

Suzuki K, Terakawa T, Jimbo N, Inaba R, Nakano Y \& Fujisawa M 2020 Clinical features of treatment-related neuroendocrine prostate cancer: a case series. Anticancer Research 40 3519-3526. (https://doi. org/10.21873/anticanres.14340)

Tolis G, Ackman D, Stellos A, Mehta A, Labrie F, Fazekas AT, ComaruSchally AM \& Schally AV 1982 Tumor growth inhibition in patients with prostatic carcinoma treated with luteinizing hormone-releasing hormone agonists. PNAS 79 1658-1662. (https://doi.org/10.1073/ pnas.79.5.1658)

Touijer KA, Karnes RJ, Passoni N, Sjoberg DD, Assel M, Fossati N, Gandaglia G, Eastham JA, Scardino PT, Vickers A, et al. 2018 Survival outcomes of men with lymph node-positive prostate cancer after radical prostatectomy: a comparative analysis of different postoperative management strategies. European Urology 73 890-896. (https://doi.org/10.1016/j.eururo.2017.09.027)
Trachtenberg J, Gittleman M, Steidle C, Barzell W, Friedel W, Pessis D, Fotheringham N, Campion M, Garnick MB \& Abarelix Study Group 2002 A phase 3, multicenter, open label, randomized study of abarelix versus leuprolide plus daily antiandrogen in men with prostate cancer. Journal of Urology 167 1670-1674. (https://doi.org/10.1097/00005392200204000-00021)

Wirth MP, Hakenberg OW \& Froehner M 2007 Antiandrogens in the treatment of prostate cancer. European Urology 51 306-313. (https:// doi.org/10.1016/j.eururo.2006.08.043)

Yadav MP, Ballal S, Sahoo RK, Dwivedi SN \& Bal C 2019 Radioligand therapy with (177)Lu-PSMA for metastatic castration-resistant prostate cancer: a systematic review and meta-analysis. American Journal of Roentgenology 213 275-285. (https://doi.org/10.2214/AJR.18.20845)

Zhang X, Coleman IM, Brown LG, True LD, Kollath L, Lucas JM, Lam HM, Dumpit R, Corey E, Chery L, et al. 2015 SRRM4 expression and the loss of REST activity may promote the emergence of the neuroendocrine phenotype in castration-resistant prostate cancer. Clinical Cancer Research 21 4698-4708. (https://doi.org/10.1158/1078-0432.CCR-15-0157)

Received in final form 9 June 2021

Accepted 15 June 2021 (c) 2021 Society for Endocrinology Published by Bioscientifica Ltd. Printed in Great Britain 